Discussion Paper No. 09-068

\title{
The Design Paradox:
}

The Contribution of In-house and

External Design Activities on

Product Market Performance

Dirk Czarnitzki and Susanne Thorwarth

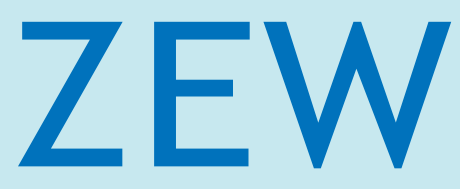

Zentrum für Europäische Wirtschaftsforschung $\mathrm{GmbH}$

Centre for European

Economic Research 
Discussion Paper No. 09-068

\section{The Design Paradox: The Contribution of In-house and External Design Activities on Product Market Performance}

Dirk Czarnitzki and Susanne Thorwarth

Download this ZEW Discussion Paper from our ftp server:

ftp://ftp.zew.de/pub/zew-docs/dp/dp09068.pdf

Die Discussion Papers dienen einer möglichst schnellen Verbreitung von neueren Forschungsarbeiten des ZEW. Die Beiträge liegen in alleiniger Verantwortung der Autoren und stellen nicht notwendigerweise die Meinung des ZEW dar.

Discussion Papers are intended to make results of ZEW research promptly available to other economists in order to encourage discussion and suggestions for revisions. The authors are solely responsible for the contents which do not necessarily represent the opinion of the ZEW. 


\section{Non-technical Summary}

Competition forces firms to find new ways to advance in the market and be innovative in order to differentiate themselves from rivals. Design activities may be one of several key factors contributing to new product development. The success story of Apple's iPod has shown that the right design can be a decisive factor when a new product enters the market.

During the recent past, scholars justified the opinion that R\&D activities conducted in-house by a company are not the only way to acquire new technological knowledge and to produce innovations. This issue has also attracted attention within the context of open innovation amongst scholars, policy makers and business leaders who have recognized the pronounced role of external knowledge flows within the innovation system. Several studies have already dealt with the impact of design on general company performance or innovation outcome. They, however, did not specifically link design to collaborative or externally sourced innovation.

This paper empirically investigates the impact of design activities and their collaborative pattern on a firm's innovation performance. To be more precise, we assess the question how market novelties or products which have only been slightly improved, i.e. are only new to the firm but not to the market, are driven by design issues. We use a sample of Belgian firms stemming from the fifth wave of the Community Innovation Survey (CIS) and show that design activities supplement a firm's innovation performance. Moreover, we find that the success of market novelties is driven by design which is mainly conducted in-house, while success of products only new to the firm is also influenced by design activities developed with external partners. This phenomenon which we label as the "design paradox" may be due to possible spillover effects and leakage of information to outsiders caused by collaboration with external partners. 


\section{Das Wichtigste in Kürze}

Unternehmen, die auf hart umkämpften Märkt bestehen wollen, brauchen ein starkes Profil, damit sie von Kunden wahrgenommen werden. Wie das Beispiel des Apple iPod gezeigt hat, ist gerade das Design eines Produkts ein entscheidender Faktor, um sich von seinen Konkurrenten zu differenzieren.

In jüngster Vergangenheit wurde bereits häufiger gezeigt, dass interne Forschungs- und Entwicklungsaktivitäten oftmals nicht den einzigen Weg zum Erwerb neuen technischen Wissens und der Generierung von Innovationen darstellen. Vielmehr postulieren Wissenschaftler in diesem Zusammenhang die Öffnung des Innovationsprozesses („open innovation“) und somit die aktive, strategische Nutzung von externem Wissen zur Steigerung des eigenen Innovationspotentials. Obwohl diverse Studien sich bereits mit der Wirkung von Designaktivitäten auf die Innovationsleistung eines Unternehmens beschäftigt haben, wurde nicht untersucht inwieweit interne bzw. externe Wissensquellen von Designaktivitäten diesen Einfluss determinieren.

Das vorliegende Diskussionspapier beschäftigt sich empirisch mit dieser Fragestellung. Es wird untersucht, wie sich Designinnovationen auf Produktinnovationen auswirken. Dabei werden Marktneuheiten von solchen Produkten unterschieden, die lediglich neu für das betreffende Unternehmen sind, nicht jedoch für den Markt. Anhand der fünften Welle des belgischen „Community Innovation Surveys“ (CIS) zeigen wir nicht nur, dass Designaktivitäten den Innovationsoutput eines Unternehmens forciercen, sondern unsere Ergebnisse illustrieren darüberhinaus, dass mit externen Wissensquellen durchgeführte Designaktivitäten lediglich zu höheren Umsätzen mit Produktneuheiten auf Unternehmensebene nicht jedoch zu Marktneuheiten führen. Der Erfolg dieser hängt hingegen deutlich von unternehmensinternen Designaktivitäten ab. Dieses Phänomen, welches wir in diesem Kontext als „Design Paradoxon“ bezeichnen, ergibt sich möglicherweise durch das Vorhandensein möglicher Spillovereffekte und „Durchsickern“ von Informationen an Außenstehende, die durch externe Wissenskollaborationen entstehen können. 


\title{
The Design Paradox: \\ The Contribution of In-house and External Design Activities on Product Market Performance ${ }^{1}$
}

\author{
Dirk Czarnitzki ${ }^{\text {a,b,c,d }}$ and Susanne Thorwarth ${ }^{\text {a,b,c }}$ \\ ${ }^{a}$ K.U.Leuven, Dept. of Managerial Economics, Strategy and Innovation \\ ${ }^{b}$ Centre for R\&D Monitoring (ECOOM) at K.U.Leuven \\ ${ }^{c}$ Centre for European Economic Research (ZEW), Mannheim \\ ${ }^{d}$ Centre for Industrial Economics, University of Copenhagen
}

September 2009

\begin{abstract}
This paper explores the contribution of design activities on product market performance of Belgian companies. While there is mounting evidence that design can be seen as a strategic tool to successfully spur sales of new product developments at the firm level, the topic of design innovation has not been linked to the open innovation concept yet. In this paper we empirically test whether design activities conducted in-house differ in their contribution to new product sales from externally acquired design. Using a large crosssection of manufacturing and service firms, we investigate the effects on sales of products new to the market and of imitation or significantly improved products of the firm. At first glance, we find the paradox that externally acquired design is not superior to in-house design activities. This effect is robust to several modifications of the model specification. As earlier literature on new technological developments in high-tech sectors, we argue, however, that external design may not affect the sales of market novelties as the "market news" may spill-over quickly to rivals through common customers and suppliers including external designers.
\end{abstract}

Keywords: Design, R\&D, Collaboration, Open Innovation, Product Market Performance JEL-Classification: O31, O32

\section{Contact:}

Dirk Czarnitzki, K.U.Leuven, Dept. of Managerial Economics, Strategy and Innovation, Naamsestraat 69, 3000 Leuven, Belgium;

E-Mail: dirk.czarnitzki@econ.kuleuven.be; Phone: +32 16326 906; Fax: +32 16326732

Susanne Thorwarth, K.U.Leuven, Centre for R\&D Monitoring,

Dekenstraat 2, 3000 Leuven, Belgium;

E-Mail: susanne.thorwarth@econ.kuleuven.be; Phone: +32 16325 735; Fax: +32 16325799

\footnotetext{
${ }^{1}$ We thank Christoph Grimpe for helpful comments.
} 
"I hope people are starting to see design is making a difference."

\section{Introduction}

Design and its contribution to product development and business performance has recently attracted attention among academics and professionals (e.g. Gemser and Leenders 2001, Platt et al. 2001, Hertenstein et al. 2005, Marsili and Salter 2006). More and more companies have been raising their budgets for design and included external design consulting firms like e.g. IDEO, Fuseproject, Zipa or Whipsaw ${ }^{2}$ in their product development process. Gemser and Leenders (2001) state that design budgets of European and American firms have been growing between 8 and 20 percent per year in the recent past.

Studies have also shown that research and development (R\&D) are - although undoubtedly a key driver - not the only factors which lead to successful product innovation (see e.g. Rammer et al. 2009). Design may be seen as one of several key factors contributing to new product development along with research and development (R\&D), marketing, manufacturing, purchasing etc. (Hertenstein et al. 2005). As early as in 1984, Kotler and Rath have already emphasized that "design is a potent strategic tool that companies can use to gain a sustainable competitive advantage, yet most companies neglect design as a strategic tool. What they don't realize is that good design can enhance products, environment, communications, and corporate identity." Von Stamm (2004) also argues that designers have an important contribution to make to the innovation process. If innovation is the goal of a company then design is an essential component in realizing this entrepreneurial objective. The success story

\footnotetext{
${ }^{2}$ In the 2008 International Design Excellence Awards (IDEAs) these four design firms were the most successful ones with IDEA taking seven awards, Fuseproject with five and Zipa as well as Whipsaw with four apiece (Nussbaum 2008).
} 
of Apple's iPod has shown that the right design can be a decisive factor when a new product enters the market since it will make users feel that the product is more attuned to their needs. This example shows that nowadays companies are more and more trying to design their products as fashion accessories. Furthermore, Yamamoto and Lambert (1994) have also shown that even for industrial products, aesthetics affect a customer's product preference.

Verganti (2008) states that innovation may be seen as the result of a process of generation and integration of knowledge. The question we address in this study is where does this knowledge come from in the case of design activities? Is it only conducted in-house or do firms also make use of external knowledge flows in terms of e.g. collaborative partnerships? Several authors have already shown that firms show a better innovation performance if they combine their internal knowledge with external knowledge (e.g. Cassiman and Veugelers 2002, 2006, Belderbos et al. 2004, 2008). This issue has also recently attracted attention within the context of open innovation (Chesbrough 2003a, 2003b, 2003c) amongst scholars, policy makers and business leaders who have recognised the pronounced role of external knowledge flows within the innovation system. Contrary to the traditional view of the closed model, open innovation treats research and development as an open system suggesting that valuable ideas can come from inside or outside the company and also can go to market from inside or outside the company (Chesbrough 2003b).

Several studies have already dealt with the impact of design on company performance or innovation outcome (e.g. Gemser and Leenders 2001, Platt et al. 2001, Hertenstein et al. 2005, Platt et al. 2001, Marsili and Salter 2006), however, they did not specifically link design to collaborative or externally sourced innovation.

This paper empirically investigates the impact of design activities and their collaborative pattern on a firm's innovation performance. To be more precise we assess the question how market novelties or products which have only slightly improved, i.e. are only new to the firm, 
but not to the market are driven by design issues. We use a sample of Belgian firms which stems from the fifth wave of the Community Innovation Survey (CIS) database and show that design activities raise a firm's innovation performance. Moreover, we find that the success of market novelties is driven by design which is mainly conducted in-house, while success of products only new to the firm is also influenced by design activities developed with external partners.

\section{R\&D, Innovation and Design}

Competition forces firms to find new ways to compete and be innovative in order to differentiate themselves from the other players in the market. In 1998, Robert H. Hayes, at that time professor at the Harvard Business School already realized: "15 years ago companies competed on price. Now it’s quality. Tomorrow it’s design.” (Baker 2006). Kotler (2003), one of the leaders in the field of marketing even proclaims that "design is the factor that will often give a company its competitive edge”.

Today, consumers cannot be satisfied with just functionality and technology, it seems that the motto "faster, better, cheaper" does not work anymore. Buying decisions are strongly influenced by emotional needs and desires, since consumers tend to identify themselves and their lifestyle with the bought product. Creative design more and more comes to the fore and many companies believe that superior design will be the key to winning customers. Especially in mature markets where technological developments only lead to marginal improvements to the consumer and also in low-tech markets, design plays a fundamental role. It has the ability to create corporate distinctiveness and also possesses the potential to give a mature product a new look. Thus, design helps to move away from the pure price competition by creating and strengthening of brands and identities (European Commission 2009, Talke et al. 2009). 
The prime example regarding the success and achievements of design is Italy or to be more precise the Lombardy region around Milan. Italian design has been known for its "edginess" and creativity already for a long time. Italian companies like Alessi, Artemide and Kartell have become worldwide leaders in their industry segment despite their small size and limited resources (Verganti 2008). Moreover, such design communities can also be found in Finland, London, Sweden, Denmark, Catalonia, and the Rhone-Alps region of France. In Helsinki, for example, many design research centres are heavily underwritten by Nokia which understands that creative design is a key factor of its mobile phones’ appeal (Verganti 2006).

\subsection{What is Design?}

Despite the growing interest in the role of design in the innovation context there has been no clear and proper definition of the term design. A classical and often cited definition of design was proposed by Krippendorff (1989) who states: “The etymology of design goes back to the latin de + signare and means making something, distinguishing it by a sign, giving it significance, designating its relation to other things, owners, users or gods. Based on this original meaning, one could say: design is making sense (of things).” Walsh (1996) points out that "the term design (as it is used in English) covers a wide range of activities: architecture, fashion design, interior design, graphic design, industrial design and engineering design.” Her classification of design is similar to the one of Borja de Mozota (2003) who distinguishes between four types of design, namely environmental design (architecture, fashion and interior), product design (industrial and engineering), package design and graphic design. All these types of design have in common that they require creative visualisation of ideas aiming at the creation of a product which does not exist in the market (Bruce and Cooper 1997).

Intrinsically, design has been linked with innovation and is also seen as the core of innovation (Bruce and Cooper 1997, Aubert 1982), “the moment when a new object is imagined, devised and shaped in prototype form” (Aubert 1982). Hence, a clearer picture of the term design 
requires the understanding what really constitutes research and development, since $R \& D$ activities play the fundamental rule in the innovation process. According to the definition of the OECD Frascati Manual (1993) which frames the methodology for collecting and using statistics about R\&D in OECD countries, the term R\&D covers three activities: basic research, applied research and experimental development. Swann and Birke (2005), Walsh (1996) and also Utterback et al. (2006) argue that design activities overlap with R\&D activities and technological innovation ${ }^{3}$. Therefore design activities make an important contribution to the innovation process. "The effective use of design is fundamental to the creation of innovative products, processes and services. Good design can significantly add value to products, lead to growth in sales and enable both the exploitation of new markets and the consolidation of existing ones” (UK Government White Paper 1995). Kotler and Rath (1984) phrase the two objectives of design as creating consumer satisfaction and generating profits for the company.

\subsection{The Impact of Design on Business Performance}

There is a growing body of evidence which addresses the relationship of design and its impact on different dimensions of company performance.

One strand of literature has analyzed the impact of design activities on general firm performance. Gemser and Leenders (2001) addressed the question on how and when integrating industrial design in the development of a new product can enhance the competitive position of a company. They used data from two Dutch manufacturing industries and showed that the extent to which design is integrated in the development process of new products has a significant positive influence on company performance. Platt et al. (2001) use several measures of financial performance and investigate 51 companies in four industries over a

\footnotetext{
${ }^{3}$ Nevertheless, design also makes a contribution to the non-innovation process of a firm through marketing, packaging, advertisement etc. of a good. For instance, a new mobile phone or car design may not comprise a fundamental technological change, but rather the modification is just due to the design.
} 
five-year time period. Their findings provide strong support for the fact that firms with good design have better financial performance. Similarly, Hertenstein et al. (2005) examine the relationship between industrial design and financial performance of a firm employing an interesting methodology. Instead of relying solely on firm-level data, they asked a panel of 138 industrial design experts to rank the design effectiveness of firms within nine selected manufacturing industries. Their results show that firms which were rated as having a good industrial design are significantly positively related to corporate financial performance and stock market performance. Cereda et al. (2005) used data from the third wave of the U.K. Community Innovation Survey (CIS) and estimate the relationship between the amount of innovative expenditure spent on design and productivity growth. Applying regressions within a production function framework they find that design expenditure has a positive impact on a firm’s labor productivity and total factor productivity growth.

Other studies consider the innovation performance of firms instead of general performance measures. Marsili and Salter (2006) investigate the impact of design expenditures on the innovation performance of Dutch manufacturing firms. By using a sample of 2010 firms from the Dutch Community Innovation Survey (CIS-2) and applying different measures of innovation performance (sales with products new to the market, new to the firm and sales with improved products) they show that design expenditures and innovation performance are directly linked. Their study also includes a measurement for openness which reflects the extent to which a firm is open to external knowledge in the innovation system for which they find a significant positive effect. However, Marsili and Salter (2006) do not directly link design with internal or external knowledge flows.

A very recent study takes the level of analysis from the firm to the product level. Talke et al. (2009) highlight by using a sample of 157 new car models launched between 1978 and 2006 
in Germany that product innovativeness is not only driven by technological novelties, but also design has become a critical element of a product's competitive advantage.

\section{Design, Collaboration and Complementary Assets}

\section{Design and internal vs. external knowledge}

The previous sections have already highlighted the importance of design for the innovation performance of a company. Successful innovation activities lead to competitive advantages which is one of the main achievements of firms. During the past years scholars justified the opinion that R\&D activities conducted in-house by a company are not the only way to acquire new technological knowledge and produce innovations. Moreover, it has been shown that strategic alliances are increasingly necessary to support innovative activities (Teece 1986, 1992). The growing technological diversification of companies demands for a successful integration of external knowledge in the innovation process.

Past research has already put a strong emphasis on the question how firms can learn from external knowledge and external resources. Cassiman and Veugelers (2002, 2006) and Veugelers (1998) found that innovating companies show a better performance when they combine internal with external innovation activities. External technology sourcing and internal research and development activities have a complementary relationship and are not substitutes (Cassiman and Veugelers 2002, Belderbos et al. 2008). Furthermore, Belderbos et al. (2004) and Aschhoff and Schmidt (2008) found a positive relationship between R\&D collaboration and innovation performance. Hoisl (2007) also points out that a combination of internal and external knowledge can result in more innovations and a better firm performance. Hence, there is evidence to suggest that many firms have shifted to the so-called model of Open Innovation which proposes the use of purposive inflows and outflows of knowledge to accelerate internal innovation and expand the markets for external use of innovation 
(Chesbrough 2003b). Chesbrough (2003a, 2003b, 2003c) emphasizes that internal R\&D stimulates a more effective monitoring and the use of external knowledge resources and networks. Von Hippel (1988) identified four external sources of useful knowledge: suppliers and customers, universities, government and private laboratories as well as competitors. Moreover, Laursen and Salter (2006) have shown that firms who are more open to external sources are more likely to have a higher level of innovation performance ${ }^{4}$.

Also in the design process a common trend towards external design skills has emerged during the last years. Due to cost and control factors firms are increasingly outsourcing design activities (Bruce and Cooper 1997). Bertola and Teixeira (2003) who examined 30 cases in which design was applied as a strategic competence for the development of product and process innovation, state that even when firms tend to rely on their internal knowledge network to promote innovation, they still tend to access external design consultants to bring new knowledge and expertise inside their company.

A good example to illustrate design in the different context of knowledge origins is the divergent case of the Sony walkman versus the Apple iPod. Sony mainly used its in-house sources and laboriously developed the walkman. They employed designers to develop the product's topology and form for different market segments (e.g. sports, children etc.). The development of the Apple iPod which has been viewed as an ecology of innovation” or an “iPod economy” is a completely different story: much of the underlying design was done outside the company (Utterback et al. 2006). However, Shermann (2002) points out that "it would be a huge mistake to assume that all the design work happened elsewhere and that Apple had no substantial input.” Apple's own contribution on its road to success consisted of

\footnotetext{
${ }^{4}$ Nevertheless, they also found that this relationship between a firm's search strategy (that is a firm's effort to identify promising external knowledge sources) and innovation performance is curvilinear indicating that “over search” may also hinder innovative output.
} 
"putting it all together and optimizing the design to eke out the best performance." Although the recent literature points towards the merits of acquiring external knowledge the latter example shows that design activities which have been conducted only by in-house resources of a company do not necessarily perform worse than those which have been developed with the help of external knowledge flows. Sony has led the worldwide market for personal stereos with a market share of around 50\% for over a decade (Sanderson and Uzumeri 1995).

\section{Design and Complementary Assets}

In almost all cases the appropriability of the returns of innovation or in other words the successful commercialisation of innovation requires the utilisation of know-how in conjunction with complementary capabilities or assets controlled by the firm, such as complementary components, distribution channels, production, and service (Teece 1986). Complementary assets are of vital importance in creating sustainable competitive advantages and innovations (Stieglitz and Heine 2007). They allow firms to gain profits from an innovation even if they are not the sole supplier of this innovation. A well-known case to name here is again the Sony walkman. It was so successful in the personal stereo market although it faced quite a large number of competitors after Sony had introduced the walkman in the market and the walkman was not inherently superior to the other products of its rivals. However, through effective design, marketing and communications Sony was able to obtain a large share of the personal stereo market (see e.g. Sanderson and Uzumeri 1995). Moreover, Sony was able to charge a price 25 percent higher than those of its competitors with the same technology. Design was widely acknowledged to be the enabler of this price differential (von Stamm 2008). A similar development can be observed with Nokia and its success on the market of mobile phones or also with the Apple iPod on the market for mp3 players. Tether (2005) argues that an important complementary asset for design can be the perceptions of customers regarding the symbolic and functional qualities of a product. Design can make a 
significant contribution towards the reputation and credibility of a product through branding, styling and other forms of communication. However, this symbolic value is not easy to build, otherwise the rivals of Sony and Nokia could have easily done the same. Design plays a crucial role regarding the self-identification of consumers with the product and thus encourages them to pay more than they otherwise might pay for essentially the same standard of technology or product. For example, Audi and Skoda comprise very much of the same technology and engineering platforms (which might be the case since they both belong to the Volkswagen Group), however due to strong marketing and branding consumers have different perceptions of the qualities and performance of Audi and Skoda cars. This leads to the conclusion that the exploitation of design will be greatest in those firms which already have complementary assets, that is they already build up some positive reputation in the relevant market.

\section{Data, Econometric Methods, and Results}

\subsection{Database}

We use firm level data stemming from the Flemish part of the fifth Community Innovation Survey (CIS) and refer to the years from 2004 to 2006. The CIS is a business survey collecting data on innovation inputs and outputs, and is to a large extent harmonized across European Member states (see Eurostat, 2004, for a detailed description of the CIS at European level). Our database contains information on a cross-section of firms active in the manufacturing sector and in selected business services and constitutes a representative sample of these sectors in the economy of Flanders. The sample comprises 1,511 firm observations. 


\section{Dependent Variables}

We use different measures of innovation performance as dependent variables in our analysis. The CIS provides direct measures of innovation output, as firms' total sales can be broken into three different categories ${ }^{5}$ :

- $\quad$ Sales in the year 2006 that are due to products introduced to the market between 2004 and 2006 and which were new to the market, that is, no comparable rival product existed before. Thus, this variable measures the sales of innovative products constituting market novelties (NEW_TO_MARKET).

- $\quad$ Sales in the year 2006 that are due to products introduced to the market between 2004 and 2006 that were not new to the market. These products were only new in the respective firm's portfolio, but there were comparable rival products on the market before (IMITATION).

- $\quad$ Sales in the year 2006 stemming from products that were in the firm's portfolio before 2004.

We first consider the sum of the first two types of new product sales as dependent variable (INNOVATION), and then break INNOVATION into NEW_TO_MARKET and IMITATION. As the distribution of these variables is quite skewed, the variables are used in logarithmic form in the upcoming regression analysis, $\ln (1+$ INNOVATION $), \ln \left(1+N E W \_T O \_M A R K E T\right)$ and $\ln (1+$ IMITATION $)$. We add the value 1 to the variables as not all firms achieve positive sales figures with innovative products.

When relating the innovation performance of the year 2006, we use lagged values of the timevarying covariates whenever this is possible to avoid a simultaneity bias which can arise if

\footnotetext{
${ }^{5}$ New products are defined in concordance with the OSLO Manual which contains guidelines for collecting and using data on industrial innovation (OECD/Eurostat, 2005).
} 
there are feedback effects from the dependent variable to current explanatory variables. Typically, the covariates used will correspond to the years 2004 to 2006.

\section{Design-related variables}

The key explanatory variables indicate whether a firm has carried out design activities between 2004 and 2006. Initially we just consider a dummy, DESIGN, taking the value 1 if the firm engaged into design activities, and is equal to zero otherwise. ${ }^{6}$

Moreover, we are interested in the way these design activities have been conducted. Did firms mainly conduct design activities in-house or did they also utilize external information and/or external designers? The question to address here is which strategy of a firm may lead to significant increases in the innovation output. Do design activities which have been developed only with internal resources lead to a greater success than those that have been carried out with external sources of knowledge? Consequently, we split the DESIGN dummy into

- DESIGN_INT indicating that a firm mainly conducted its design activities within its own enterprise or enterprise group;

- DESIGN_EXT denoting a firm that conducted its design activities together with other enterprises or institutions, or that relied completely on external designers without own in-house activities. ${ }^{7}$

\section{Control variables}

Of course, the main input factor for innovation is R\&D. Consequently, R\&D intensity (RDINT) is included as an explanatory variable in all models. R\&D intensity is defined by R\&D expenditures divided by a firm’s employees. Although we would prefer using a lagged

\footnotetext{
${ }^{6}$ In this study we rely on the definition of design based on the Oslo Manual and the Frascati Manual (OECD/Eurostat 2005).

${ }^{7}$ The case that a firm only seeks external design without any in-house activity is almost non-existent. Only $0.3 \%$ of the sample indicated this. Therefore we do not consider this as separate case in the empirical analysis.
} 
value for R\&D, we only have this information from the year 2006. Thus, we have to use it as a proxy for the average R\&D activities between 2004 and 2006. We allow for a non-linear relationship by including the squared $R \& D$ intensity in the regression $\left(R D I N T^{2}\right)$.

We have outlined above that several other complementary assets and innovation strategies may be needed for successful innovation. As we distinguish between internal and external design, the general openness of the innovation process may play a role. We control for this by taking a firm's collaboration behaviour into account. The CIS 2007 asked respondents to specify their different types of partners they have collaborated with in the course of innovation activities between the years 2004 and 2006. In our first specification, we consider just a dummy variable indicating whether a firm collaborated within its innovation project, irrespectively of the type of partner $(C O L L)$. In a further step, we split the collaboration dummy by type of partner. The following categories are specified:

\section{Collaboration with:}

- Other companies within the group of companies (ACOLL)

- Suppliers of materials, equipment and software components (BCOLL)

- Customers and consumers (CCOLL)

- Competitors or other companies in the same industry (DCOLL)

- Consultants (ECOLL)

- Universities or other research centres (FCOLL)

The set of variables consist of six dummy variables (ACOLL, BCOLL, CCOLL; DCOLL, ECOLL and FCOLL) which take the value 1 if the firms have indicated a collaboration partnership within the different categories and 0 otherwise.

As Teece (1986) emphasized, successful innovation also depends on a firm's distribution channels, production, and services. In terms of distribution, investments in marketing and market launch strategies help to build up the reputation of a product. It is most likely, that 
firms which heavily invest in those strategies sell more of their innovative products than others. Hence, to account for this distribution effect we use the dummy variable $M L A U N C H$. This dummy variable has the value 1 if the firm has invested in market launch strategies for product innovations between 2004 and 2006 which also include market research and advertisement and 0 otherwise. Furthermore, we take into account that firms may be associated with a group of companies which may facilitate access to markets and thus also improve the distribution of new products. The variable GROUP takes the value 1 if a firm is member of a group of companies between 2004 and 2006.

With regard to the importance of production and service factors, we control for economies of scale and scope by accounting for firm size which is measured by the number of employees in the year 2004. Due to the skewness of its distribution, the variable enters the regression equation in log-linear form $(\ln E M P L)$.

Our ability to control for brand name reputation is fairly limited with the data. However, we use the age of the firm ( $\ln A G E$ ) as a rough proxy for market experience and reputation. Finally, ten sector dummies on basis on the European standard industry classification NACE capture different technological opportunities and other unobserved factors varying across industries (see Table 4 in appendix A).

Descriptive statistics of the variables are presented in Table 1 where we split the sample into firms employing design in their business strategy and others. The majority of firms $(1,243$ observations) in the sample did not indicate design innovation. Only 268 firms employ design activities in their business strategy. Overall, firms that indicate design activities achieve higher average innovation output on all three dependent variables. However, these firms are also more than twice as large as the other firms and maintain a much higher R\&D intensity (R\&D spending per employee). In the design sample, R\&D amounts to 12.5 thousand EUR per employee, on average. The other firms only spend about 4.1 thousand EUR per employee. 
Other striking differences are found in the innovation strategies: about $59 \%$ of the firms in the design sample engage in collaboration within their innovation projects whereas only $23 \%$ of the other firms do this. Furthermore, 65\% of firms actively utilizing design combined their innovation projects with market launch strategies, but only $16 \%$ of the other firms did that. Within the design sample, $70 \%$ of firms indicated that design activities are mainly conducted in-house, and the other $30 \%$ use external sources, too. These differences in firm characteristics make a multivariate analysis necessary. In this study, we are interested whether the differences in innovation output can partly be assigned to design activities, once we control for the heterogeneity in other firm attributes. 
Table 1: Descriptive Statistics (1511 observations)

\begin{tabular}{|c|c|c|c|c|c|}
\hline Variable & Unit & Mean & Std. Dev. & Min & Max \\
\hline \multicolumn{6}{|c|}{ If a firm exhibits design activities, $N E W \_D E S I G N=1$ (268 observations) } \\
\hline \multicolumn{6}{|l|}{ Dependent Variable } \\
\hline$N E W_{-} T O \_M A R K E T_{2006}$ & Thsd. EUR & 16938.04 & 95669.99 & 0 & 1025198 \\
\hline IMITATION $_{2006}$ & Thsd. EUR & 10151.14 & 53460.41 & 0 & 706128 \\
\hline INNOVATION $_{2006}$ & Thsd. EUR & 27089.18 & 123815.5 & 0 & 1025198 \\
\hline \multicolumn{6}{|l|}{ Design Variables } \\
\hline INT_DESIGN $2004-2006$ & Dummy & 0.702 & 0.458 & 0 & 1 \\
\hline$E X T \_D E S I G N_{2004-2006}$ & Dummy & 0.299 & 0.458 & 0 & 1 \\
\hline \multicolumn{6}{|l|}{ Collaboration Variables } \\
\hline$C O L L_{2004-2006}$ & Dummy & 0.590 & 0.493 & 0 & 1 \\
\hline$A C O L L_{2004-2006}$ & Dummy & 0.299 & 0.459 & 0 & 1 \\
\hline$B C O L L_{2004-2006}$ & Dummy & 0.448 & 0.498 & 0 & 1 \\
\hline$C C O L L_{2004-2006}$ & Dummy & 0.366 & 0.483 & 0 & 1 \\
\hline$D C O L L_{2004-2006}$ & Dummy & 0.168 & 0.375 & 0 & 1 \\
\hline$E C O L L_{2004-2006}$ & Dummy & 0.377 & 0.486 & 0 & 1 \\
\hline FCOLL $L_{2004-2006}$ & Dummy & 0.411 & 0.493 & 0 & 1 \\
\hline \multicolumn{6}{|l|}{ Control Variables } \\
\hline MLAUNCH $2004-2006$ & Dummy & 0.649 & 0.478 & 0 & 1 \\
\hline$E M P L_{2004}$ & Head Counts & 241.230 & 594.995 & 1 & 5399 \\
\hline$R D I N T_{2006}$ & $R \& D$ Exp. per employee & 12.541 & 35.587 & 0 & 320 \\
\hline GROUP $_{2004-2006}$ & Dummy & 0.571 & 0.496 & 0 & 1 \\
\hline$A G E_{2006}$ & Years elapsed since founding & 36.586 & 31.928 & 1 & 182 \\
\hline \multicolumn{6}{|c|}{ If a firm does not conduct design activities, NEW_DESIGN =0 (1243 observations) } \\
\hline \multicolumn{6}{|l|}{ Dependent Variable } \\
\hline$N E W_{-} T O \_M A R K E T_{2006}$ & Thsd. EUR & 1045.022 & 8574.11 & 0 & 261184 \\
\hline IMITATION $_{2006}$ & Thsd. EUR & 1513.475 & 14414.38 & 0 & 424122 \\
\hline INNOVATION $_{2006}$ & Thsd. EUR & 2558.498 & 18003.71 & 0 & 424122 \\
\hline \multicolumn{6}{|l|}{ Design Variables } \\
\hline INT_DESIGN $2004-2006$ & Dummy & 0 & 0 & 0 & 0 \\
\hline EXT_DESIGN $2004-2006$ & Dummy & 0 & 0 & 0 & 0 \\
\hline \multicolumn{6}{|l|}{ Collaboration Variables } \\
\hline$C O L L_{2004-2006}$ & Dummy & 0.234 & 0.424 & 0 & 1 \\
\hline$A C O L L_{2004-2006}$ & Dummy & 0.110 & 0.313 & 0 & 1 \\
\hline$B C O L L_{2004-2006}$ & Dummy & 0.164 & 0.371 & 0 & 1 \\
\hline$C C O L L_{2004-2006}$ & Dummy & 0.118 & 0.322 & 0 & 1 \\
\hline$D C O L L_{2004-2006}$ & Dummy & 0.053 & 0.224 & 0 & 1 \\
\hline$E C O L L_{2004-2006}$ & Dummy & 0.105 & 0.306 & 0 & 1 \\
\hline$F C O L L_{2004-2006}$ & Dummy & 0.142 & 0.349 & 0 & 1 \\
\hline \multicolumn{6}{|l|}{ Control Variables } \\
\hline MLAUNCH ${ }_{2004-2006}$ & Dummy & 0.165 & 0.371 & 0 & 1 \\
\hline$E M P L_{2004}$ & Head Counts & 99.575 & 262.412 & 1 & 4089 \\
\hline$R D I N T_{2006}$ & $R \& D$ Exp. per employee & 4.148 & 19.193 & 0 & 329.646 \\
\hline$G_{R O U P} 2004-2006$ & Dummy & 0.485 & 0.500 & 0 & 1 \\
\hline$A G E_{2006}$ & Years elapsed since founding & 31.576 & 26.767 & 2 & 257 \\
\hline
\end{tabular}

Note: Industry dummies not presented. 


\subsection{Estimation method}

We estimate Tobit models on our different innovation performance measures since not every firm in our sample shows a positive number of NEW_TO_MARKET, IMITATION and consequently, also INNOVATION. Hence, the distribution of our dependent variable is leftcensored. The model to be estimated can be written as follows:

$$
Y_{i}^{*}=X_{i}^{\prime} \beta+\varepsilon_{i}, \quad \text { with } \quad \varepsilon_{i} \sim N\left(0, \sigma^{2}\right)
$$

where $Y^{*}$ is the unobserved latent variable and stands either for NEW_TO_MARKET, IMITATION or INNOVATION. We observe

$$
Y=\left\{\begin{array}{l}
Y^{*} \text { if } X^{\prime} \beta+\varepsilon>0 \\
0 \text { otherwise }
\end{array}\right.
$$

$X$ represents a matrix of regressors, $\beta$ are the parameters which have to be estimated and $\varepsilon$ is the disturbance term. Our baseline equation to be estimated is the following:

$$
\begin{aligned}
Y_{2006}^{*} & =\beta_{1}+\beta_{2} \ln E M P L_{2004}+\beta_{3} \ln \operatorname{RDINT}_{2006}+\beta_{4}\left(\ln \text { RDINT }_{2006}\right)^{2} \\
& +\beta_{5} \text { DESIGN }_{2004-2006}+\beta_{6} \operatorname{COLL}_{2004-2006}+\beta_{7} \text { RMAR }_{2004-2006} \\
& +\beta_{8} \text { GROUP }_{2004-2006}+\beta_{9} \ln \text { AGE }_{2006}+\sum_{k=10}^{20} \beta_{k} \text { Sector }_{k}+\varepsilon
\end{aligned}
$$

In the modified specification, we break the design dummy into "mainly in-house design" and external design, and the collaboration dummy is split into the different types of partners as described above.

As heteroscedasticity may lead to inconsistent coefficient estimates, we tested for heteroscedasticity using Likelihood Ratio (LR) tests. This required the estimations of heteroscedastic models, where the homoscedastic variance $\sigma^{2}$ has been replaced by $\sigma_{i}^{2}=\sigma^{2} \exp \left(Z_{i}^{\prime} \alpha\right)$, where $Z_{i}^{\prime}$ is a vector of variables suspected to cause heteroscedasticity. As common in the field, we model group-wise multiplicative heteroscedasticity (see e.g. Greene, 
2002) and included firms' size class dummies based on the number of employees and industry dummies in Z. We performed the LR tests for all models presented below. The LR statistic did never reject the assumption of homoscedasticity. Consequently, we only present the homoscedastic models.

\subsection{Results}

\subsubsection{Baseline specification}

The regression results concerning our baseline specification are presented in Table 2. In all three regressions, the design dummy is highly positively significant at the $1 \%$ level. Thus, even when controlling for firm characteristics, we find that design contributes to firms' innovation performance. Note, however, that the coefficients denote the partial effects of the explanatory variables on the unobserved latent variable $Y^{*}$. For a better economic interpretation, we are interested in the marginal effect $\partial E(Y \mid X) / \partial x_{k}$, i.e. the effect of the explanatory variable on the observed dependent variable, or in other words, when the censoring of the distribution is taken into account. We obtained standard errors for the marginal effects using the delta method. As the significance levels of the variables do not change, we do not present all these effects in detail, but discuss selected marginal effects in the text.

As the dependent variables are measured as logs of innovation sales, the marginal effect of a change in $x_{k}$ approximated the percentage change (or growth) of the dependent variable. In terms of total innovation output, the firms employing design achieve a $130 \%$ higher innovation output than other firms. With regard to sales of market novelties, the marginal effect of design amounts to $83 \%$ higher sales, and $100 \%$ more for product innovations that are only new to the firm, but not to the market. 
Although these numbers appear to be a very large impact, one should keep in mind that the sales due to product innovations are typically only a small share of a firm's total sales. On average, sales with market novelties amount to $5 \%$ of a firm's total sales, and new products based on imitation range at $4.4 \%$, on average. Thus, the sizeable marginal effect of an $83 \%$ increase of sales with market novelties because of design activities, for instance, is by no means implausible: the average share of sales with market novelties would move from $5 \%$ in total sales to about $9 \%$, all else constant.

Table 2: Regression results of Tobit models on innovation performance (baseline specification)

\begin{tabular}{lccc}
\hline & \multicolumn{3}{c}{ Dependent Variable (in logs) } \\
Variable & NEW_TO_MARKET & IMITATION & INNOVATION \\
\hline DESIGN & $2.668^{* * *}$ & $3.486^{* * *}$ & $2.934^{* * *}$ \\
COLL & $(0.540)$ & $(0.636)$ & $(0.476)$ \\
& $3.833^{* * *}$ & $3.877^{* * *}$ & $3.879^{* * *}$ \\
MLAUNCH & $(0.519)$ & $(0.607)$ & $(0.447)$ \\
& $6.341^{* * *}$ & $5.687^{* * *}$ & $5.873^{* * *}$ \\
RDINT & $(0.555)$ & $(0.647)$ & $(0.778)$ \\
& $0.096^{* * *}$ & $0.033^{* * *}$ & $0.079^{* * *}$ \\
RDINT ${ }^{2}$ & $(0.019)$ & $(0.023)$ & $(0.017)$ \\
& $0.000^{* * *}$ & $0.000^{* * *}$ & $0.000^{* * *}$ \\
In(EMPL) & $(0.000)$ & $(0.000)$ & $(0.000)$ \\
& $0.632^{* * *}$ & $1.026^{* * *}$ & $0.842^{* * *}$ \\
In(AGE) & $(0.193)$ & $(0.222)$ & $(0.164)$ \\
GROUP & 0.143 & -0.309 & -0.049 \\
& $(0.295)$ & $(0.340)$ & $(0.252)$ \\
Joint significance of industry dummies & -0.114 & 0.714 & 0.298 \\
Log-Likelihood & $(0.525)$ & $(0.609)$ & $(0.446)$ \\
McFadden $R^{2}$ & $\mathrm{~F}(9,1494)=2.83^{* * *}$ & $\mathrm{~F}(9,1494)=3.67^{* * *}$ & $\mathrm{~F}(9,1494)=4.35^{* * *}$ \\
\hline of obs & -1761.24 & -1703.62 & -2100.47
\end{tabular}

Notes: All models include an intercept (not presented). Standard errors in parentheses.

*** $(* *, *)$ indicate a $1 \%(5 \%, 10 \%)$ significance level.

In addition, collaborating firms and those implementing market launch strategies for product innovation also achieve a higher innovation performance than other firms in all three regressions. With respect to market novelties, for instance, collaborating firm achieve an 83\% higher turnover than non-collaborating firms. Market launch campaigns lead to a large difference. Firms undertaking such actions sell 225\% more of their product new to the market than other firms. While this appears to be a sizable impact, one should keep in mind that we 
have no information on the cost of the market launch strategies. Intense market research and marketing efforts may entail substantial cost, so that we cannot make a conclusion about the eventual profitability of these actions.

The results concerning the other control variables are interesting, too. As one would expect, larger firms achieve a higher innovation output for all three dependent variables, all else constant. The R\&D intensity shows an inverted U-shape which peaks at about 130 thousand. EUR of R\&D spending per employee. As this is beyond the $99 \%$ percentile of the RDINT distribution in our sample, we can basically confirm that we find increased innovation output the higher the $R \& D$ intensity of firms is. Note, however, that the $R \& D$ variables are not significant in the regression on products that are new to the firm only (IMITATION).

Except the jointly significant industry dummies capturing unobserved differences across sectors, the other control variables turn out to be insignificant (GROUP and AGE).

We performed several robustness checks which can be found in the appendix. First, we estimated the same models by OLS instead of Tobit. Although OLS does not account for censoring of the dependent variable, it does not rely on the normality assumption as the Tobit estimations. As we outline in the appendix, OLS confirms the Tobit results. Second, we tested for endogeneity of the design dummy. The hypothesis of exogeneity is not rejected, and thus the Tobit results presented are not subject to feedback effects from innovation performance to design activity. Third, we relax our functional form assumption used in the regression models presented above by applying a fully non-parametric matching estimator. Again, the estimated effects of design activities remain similar for all three dependent variables.

\subsubsection{The modified specification}

In the final step of the analysis, we simply break the DESIGN variables into internal and external design, and in addition break the collaboration dummy into the six different types of 
partners (ACOLL to FCOLL) to allow for more heterogeneity in the overall innovation strategy. The estimation results of the Tobit models are presented in Table 3.

We find interesting different effects on specific success measures. The total innovation sales are higher for firms conducting design either in-house only or mainly externally. However, when computing the marginal effects, it turns out that the in-house design performers sell $164 \%$ more than firms not actively involving new design whereas the firms mainly using external sources for design only achieve 68\% higher sales than other companies. Even more interesting are the findings concerning market novelties. In-house design realizes 113\% higher sales, but the marginal effect for mainly external sourcing for design innovation is not statistically different from zero. In addition to testing whether the marginal effects are different from zero, we also tested whether the coefficients of in-house versus external design are different from each other. These tests reject the equality of coefficients at the $5 \%$ level for both total innovation sales and market novelties. For IMITATION, the two design variables are positively significant (in-house resulting in $117 \%$ higher sales, and external design in 75\%), but a test reveals that the coefficients are not significantly different from each other (see the tests in Table 3). 
Table 3: Regression results of Tobit models on innovation performance (modified specification)

\begin{tabular}{|c|c|c|c|}
\hline \multirow[b]{2}{*}{ Variable } & \multicolumn{3}{|c|}{ Dependent Variable (in logs) } \\
\hline & NEW_TO_MARKET & IMITATION & INNOVATION \\
\hline \multirow[t]{2}{*}{ INT_DESIGN } & $3.347^{* * *}$ & $3.853^{* * *}$ & $3.497 * * *$ \\
\hline & $(0.596)$ & $(0.709)$ & $(0.531)$ \\
\hline \multirow[t]{2}{*}{$E X T \_D E S I G N$} & 0.566 & $2.574 * * *$ & $1.575^{* *}$ \\
\hline & $(0.833)$ & $(1.011)$ & $(0.774)$ \\
\hline \multirow[t]{2}{*}{$A C O L L$} & 0.857 & 1.003 & 1.045 \\
\hline & $(0.750)$ & $(0 . .887)$ & $(0.663)$ \\
\hline \multirow[t]{2}{*}{$B C O L L$} & $2.306 * * *$ & 1.114 & $1.979 * * *$ \\
\hline & $(0.661)$ & $(0.790)$ & $(0.582)$ \\
\hline \multirow[t]{2}{*}{ CCOLL } & $2.079 * * *$ & $2.954 * * *$ & $2.114 * * *$ \\
\hline & $(0.731)$ & $(0.877)$ & $(0.651)$ \\
\hline \multirow[t]{2}{*}{ DCOLL } & -1.011 & -0.961 & $-1.234 *$ \\
\hline & $(0.812)$ & $(0.965)$ & $(0.732)$ \\
\hline \multirow[t]{2}{*}{ ECOLL } & 0.194 & 1.031 & 0.176 \\
\hline & $(0.698)$ & $(0.830)$ & $(0.623)$ \\
\hline \multirow[t]{2}{*}{ FCOLL } & 0.228 & -1.056 & 0.022 \\
\hline & $(0.669)$ & $(0.798)$ & $(0.592)$ \\
\hline \multirow[t]{2}{*}{ MLAUNCH } & $6.520^{* * *}$ & $6.031 * * *$ & $6.191^{* * *}$ \\
\hline & $(0.555)$ & $(0.654)$ & $(0.483)$ \\
\hline \multirow{2}{*}{ RDINT } & $0.090^{* * *}$ & 0.032 & $0.076^{* * *}$ \\
\hline & $(0.019)$ & $(0.023)$ & 0.017 \\
\hline \multirow[t]{2}{*}{$R_{D I N T^{2}}$} & $-0.000 * * *$ & -0.000 & $-0.000 * * *$ \\
\hline & $(0.000)$ & $(0.000)$ & $(0.000)$ \\
\hline \multirow[t]{2}{*}{$\ln (E M P L)$} & $0.555^{* * *}$ & $0.986 * * *$ & $0.789 * * *$ \\
\hline & $(0.196)$ & $(0.227)$ & $(0.168)$ \\
\hline \multirow[t]{2}{*}{$\ln (A G E)$} & 0.149 & -0.282 & -0.058 \\
\hline & $(0.293)$ & $(0.340)$ & $(0.252)$ \\
\hline \multirow[t]{2}{*}{ GROUP } & -0.454 & 0.390 & -0.020 \\
\hline & $(0.549)$ & $(0.639)$ & $(0.466)$ \\
\hline Joint significance of industry dummies & $\mathrm{F}(9,1494)=2.60^{* * *}$ & $\mathrm{~F}(9,1494)=3.67 * * *$ & $\mathrm{~F}(9,1494)=4.12^{* * *}$ \\
\hline $\begin{array}{l}\text { Test on equality of coefficients of } \\
\text { internal and external design }\end{array}$ & $\mathrm{F}(1,1488)=8.62 * * *$ & $\mathrm{~F}(1,1488)=1.39$ & $\mathrm{~F}(1,1488)=5.29 * *$ \\
\hline Log-Likelihood & -1756.68 & -1705.52 & -2104.75 \\
\hline McFadden $\mathrm{R}^{2}$ & 0.157 & 0.127 & 0.156 \\
\hline \# of obs & 1511 & 1511 & 1511 \\
\hline
\end{tabular}

Notes: All models include an intercept (not presented). Standard errors in parentheses.

*** $(* *, *)$ indicate a $1 \%(5 \%, 10 \%)$ significance level.

These are quite interesting findings, as the recent literature points towards the model of open innovation suggesting that valuable ideas come from inside and outside the company and that the traditional approach of "research and develop" is more and more replaced by "connect and develop" or "acquire and develop”. Thus, our findings generate a scenario which we label as the "design paradox", since only design activities conducted with internal knowledge lead to higher sales of market novelties. However, intuitively these results are justified since according to economic theory knowledge is a public good which may accrue ("spill over”) to rival firms and enables them to free-ride on the efforts of the innovating firm. Consequently, 
firms have a strong incentive to keep their knowledge proprietary or rather protect their knowledge from appropriation by competitors (Liebeskind 1997). Laursen and Salter (2005) also found that knowledge intensive small firms (hence, those companies which are often based on the exploitation of new ideas) are less likely to open to external sources. Collaboration with external experts comes along with the increasing risk of involuntary spill over effects and leakage of information to outsiders that may later become competitors or may make better use of the acquired know-how. Empirically such harming spill-over effects have been uncovered by Mansfield (1985) by surveying R\&D managers of 100 U.S. companies in high-tech sectors. It turned out that sensitive information on R\&D concerning new product development ended up in the hands of rivals after 12 to 18 months, on average. For one fifth of the firms, it only took up to 6 months before crucial knowledge spilled over to rivals. As Mansfield (1985) states, among other channels, linkages through common suppliers and customers are important channels through which a great deal of information is exchanged, and thus possibly lost to rivals. As Mansfield's study concerned detailed technological knowledge, design may even be less unique to a firm than research results. Thus, a firm relying mainly on external designers may not be able to capture a competitive edge over its rivals that may have access to the same (group of) external designers. In addition, copying design-related aspects of an innovation is certainly cheaper and easier for rivals than, for instance, gathering knowledge through reverse engineering (see e.g. Mansfield et al., 1981). ${ }^{8}$

Moreover, firms may stick to their in-house resources, because external design consultants only have insufficient knowledge about the practices of the company and also slow down the

\footnotetext{
${ }^{8}$ It should be noted, however, that Mansfield (1985) found some industry differences in the outflow of knowledge. For our case, this would suggest that the effect of external design may vary across industries. Consequently, we re-estimated the model shown in Table 3, but instead of estimating just one coefficient for external design each, we interacted the variable with industry dummies. This allowed us to test whether there are heterogeneous effects of external design depending of the industry. The regressions, however, showed that we cannot reject the hypothesis that the effect external design is equal across industries for all models.
} 
design process since they are not accessible every day (von Stamm 2003). This is a crucial point regarding the time constraints a firm is exposed to when developing a market novelty. Coordination problems with in-house design and/or other departments may also occur especially if the external design consultants deal with the innovative part of the design process while internal staff just has to integrate the design or do less attractive design activities (Cooper and Press 1995). In addition, the not invented here syndrome can arise and there may be the possibility of a credibility gap if the designed product is too different from the vision of the firm (Borja de Mozota 2003).

Regarding the R\&D collaboration pattern our results show that collaboration with suppliers has a significant positive effect on all three success measures. In the case of market novelties and new product sales we also find a positive effect of collaboration with customers and consumers. Interestingly, collaboration with competitors or other companies in the same industry shows a negative coefficient on the imitation variable, however only significant on the $10 \%$ level. The results concerning the other controls are equal to the baseline specification and are thus not discussed in further detail here.

\section{Conclusion}

In this paper, we have investigated the effects of design activities and its different knowledge origins on innovation performance. Our results provide clear evidence that design activities improve a firm's innovation performance.

Moreover, our results lead to a scenario which we label as the "design paradox", as we find that only design activities which are mainly conducted with internal knowledge play a crucial role regarding the product innovation success with market novelties. These results are in contrast to design activities leading to product imitations where the collaboration with external designers has a significant influence. By using only internal design sources the 
proprietary nature of the work is guaranteed which appears to be of primary importance if a firm intends to introduce a market novelty. If a firm collaborates with external design consultants, information about new products may leak out before the company is ready to utilize this information in the market exclusively.

Nonetheless, several economic studies which have addressed the issue of innovative performance have shown that a variety of different factors is necessary to shape innovation performance and that successful firms are usually characterised by their entrepreneurial ability across a field of different domains. Thus, design expenditures by itself cannot be the exclusive reason for a firm's innovation success, but rather the integration of a firm's capabilities such as marketing, production, distribution and other complementary assets into its product. In this sense, design expenditures can act as a catalyst for successful products since they allow firms to differentiate from rivals in the market.

Finally, it should be noted that scholars have emphasized the presence and importance of complementarities in the innovation process. Although we control for possibly the most important factors in our regressions, it would be interesting for further research to explore complementarities with design in more detail. We have searched for potential moderating effects using our covariates, but did not find any significant effects. However, especially our ability to control for brand name reputation has been limited with the given data. It would be desirable to develop more sophisticated measures for reputation which may allow exploring potentially heterogeneous effects of design across firms. 


\section{References}

Almus, M. and D. Czarnitzki (2003), The effects of public R\&D subsidies on firms' innovation activities: the case of Eastern Germany, Journal of Business and Economic Statistics 21(2), 226-236.

Aschhoff, B. and T. Schmidt (2008), Empirical Evidence on the Success of R\&D Cooperation - Happy Together? Review of Industrial Organization 33, 41 - 62.

Aubert, J.E. (1982), Innovation in Small and Medium Firms, Organisation for Economic Cooperation and Development, Paris.

Baker, R.J. (2006), Pricing on Purpose: Creating and Capturing Value, Wiley \& Sons.

Belderbos, R., M. Carree and B. Lokshin (2004), Cooperative R\&D and Firm Performance, Research Policy 33, 1477 - 1492.

Belderbos, R., M. Carree and B. Lokshin (2008), The Productivity Effects of Internal and External R\&D: Evidence from a Dynamic Panel Data Model, Oxford Bulletin of Economics and Statistics 70 (3), 399 - 413.

Bertola, P. and J. C. Teixeira (2003), Design as a knowledge agent. How design as a knowledge process is embedded into organizations to foster innovation, Design Studies 24, $181-194$.

Borja de Mozota, B. (2003), Design Management: Using Design to Build Brand Value and Corporate Innovation, Alloworth Communications Inc., New York.

Bruce, M. and R. Cooper (1997), Marketing and Design Management, Thomson Business Press, Boston.

Cassiman, B. and R. Veugelers (2002), R\&D Cooperation and Spillovers: Some Empirical Evidence from Belgium, American Economic Review 92 (4), 1169 - 1184.

Cassiman, B. and R. Veugelers (2006), In Search of Complementarity in the Innovation Strategy: Internal R\&D and External Knowledge Acquisition, Management Science 52 (1), 68-82.

Cereda, M., G. Crespi, C. Criscuolo and J. Haskel (2005), Design and Company Performance: Evidence from the Community Innovation Survey, DTI Report.

Chesbrough, H (2003a), Open Innovation, Harvard Business School Press, Boston.

Chesbrough, H (2003b), Open Innovation: A New Paradigm for Understanding Industrial Innovation, in H. Chesbrough, W. Vanhaverbeke and J. West (eds.), Open Innovation: Researching a New Paradigm, Oxford: Oxford University Press.

Chesbrough, H. (2003c), The Era of Open Innovation, MIT Sloan Management Review 44 (3), 35-41.

Cooper, R. and M. Press (1995), The Design Agenda, John Wiley and Sons, Chichester.

Czarnitzki, D. and G. Licht (2006), Additionality of Public R\&D Grants in a Transition Economy: The Case of Eastern Germany, Economics of Transition 14 (1): 101-131.

European Commission (2009), Design as a Driver of User-Centred Innovation, Commission Staff Working Document, Brussels. 
Eurostat (2004), Innovation in Europe - Results for the EU, Iceland and Norway, Panorama of the European Union - Theme 9: Science and Technology, Luxembourg.

Gemser, G. and M.A.A.M. Leenders (2001), How integrating industrial design in the product development process impacts on company performance, Journal of Product Innovation Management 18, 28 - 38.

Greene, W.H. (2002), Econometric Analysis, Prentice Hall, New Jersey.

Heckman, J.J., R.J. Lalonde and J.A. Smith (1999), The Economics and Econometrics of Active Labour Market Programs, in: A. Ashenfelter and D. Card, Handbook of Labour Economics, Amsterdam, Vol. 3, 1866-2097.

Hertenstein, J.H., M.B. Platt and R.W. Veryzer (2005), The Impact of Industrial Design Effectiveness on Corporate Financial Performance, Journal of Product Innovation Management 22, 3 - 21.

Hoisl, K. (2007), Tracing mobile inventors - The causality between inventor mobility and inventor productivity, Research Policy 36(5), 619 - 636.

Imbens, G.W. and J.M. Wooldridge (2009), Recent Developments in the Econometrics of Program Evaluation, Journal of Economic Literature 47(1), 5 - 86.

Kotler, P. and G. A. Rath (1984), Design a powerful but neglected strategic tool, Journal of Business Strategy 5(2), 16 - 21.

Kotler, P. (2003), Marketing Management, 11th ed., Upper Saddle River, Prentice-Hall, New Jersey.

Krippendorff, K. (1989), On the Essential Contexts of Artifacts or on the Proposition that “Design Is Making Sense (of Things)”, Design Issues 5(2), 9 - 38.

Laursen, K. and A. Salter (2005), The Paradox of Openness: Appropriability and the Use of External Sources of Knowledge for Innovation, mimeo.

Laursen, K. and A. Salter (2006), Open for innovation: the role of openness in explaining innovation performance among UK manufacturing firms, Strategic Management Journal 27, 131-150.

Lechner, M. (2001), Identification and estimation of causal effects of multiple treatments under the conditional independence assumption, in: M. Lechner and F. Pfeiffer (eds.), Econometric evaluation of active labor market policies, Heidelberg, 43-58.

Liebeskind, J.P. (1997), Keeping Organizational Secrets: Protective Institutional Mechanisms and their Costs, Industrial and Corporate Change 6, 623 - 663.

Mansfield, E. (1985), How Rapidly does New Industrial Technology Leak Out? Journal of Industrial Economics 34(2), 217 - 223.

Mansfield, E., Schwartz, M. and S. Wagner (1981), Imitation Costs and Patents: An Empirical Study, Economic Journal 91, 907-918.

Marsili, O. and A. Salter (2006), The Dark Matter of Innovation: Design and Innovative Performance in Dutch Manufacturing, Technology Analysis \& Strategic Management 18 (5), $515-534$.

Nussbaum, B. (2008), The Best Global Design of 2008, Business Week, July 17. 
OECD (1993), Frascati-Manual, Proposed Standard Practice for Surveys of Research and Experimental Development, Organisation for Economic Co-Operation and Development, Paris: OECD.

OECD/Eurostat (2005), Oslo Manual, 3rd edition, Paris: OECD.

Platt, M. B., J. H. Hertenstein and D. R. Brown (2001), Valuing Design: Enhancing Corporate Performance through Design Effectiveness, Design Management Journal 12 (3), 10 19.

Rammer, C., D. Czarnitzki and A. Spielkamp (2009), Innovation Success of Non-R\&DPerformers: Substituting Technology by Management in SMEs, Small Business Economics 33, 35-58.

Sanderson, M. and Uzumeri, M. (1995), Managing Product Families: The Case of the Sony Walkman, Research Policy 24(5), 761 - 782.

Shermann, E. (2002), Inside the Apple iPod Design Triumph, Electronics Design Chain, cover story.

Smith, R. and R. Blundell (1986), An Exogeneity Test for a Simultaneous Equation Tobit Model with an Application to Labor Supply, Econometrica 54, 679-685.

Staiger, D. and J.H. Stock. 1997. Instrumental variables regression with weak instruments, Econometrica 65(3), 557-586.

Stieglitz, N. and K. Heine (2007), Innovations and the Role of Complementarities in a Strategic Theory of the Firm, Strategic Management Journal 28, 1 - 15.

Swann, P. and D. Birke (2005), How do Creativity and Design Enhance Business Performance? A Framework for Interpreting the Evidence, DTI Think Piece, Final Report, Nottingham University Business School.

Talke, K., S. Salomo, J. E. Wieringa and A. Lutz (2009), What about Design Newness? Investigating the Relevance of a Neglected Dimension of Product Innovativeness, Journal of Product Innovation Mangement 26, 601 - 615.

Teece, D. J. (1986), Profiting from technological innovation: Implications for integration, collaboration, licensing and public policy, Research Policy 15, 285 - 305.

Teece, D. J. (1992), Competition, Cooperation, and Innovation: Organizational Arrangements for Regimes of Rapid Technological Progress, Journal of Economic Behavior and Organization 18, 1-25.

Tether, B. (2005), Think Piece on the Role of Design in Business Performance, ESRC Centre for Research on Innovation and Competition (CRIC), University of Manchester.

UK Government White Paper (1995), Competitiveness: Forging Ahead, DTI Publications, HMSO, London.

Utterback, J., B. - A. Vedin, E. Alvarez, S. Ekman, S. Walsh Sanderson, B. Tether and R. Vergani (2006), Design-Inspired Innovation, World Scientific Publishing.

Verganti, R. (2006), Innovating through Design, Harvard Business Review 84 (12), 114 - 22.

Verganti, R. (2008), Design, Meanings, and Radical Innovation: A Metamodel and a Research Agenda, Journal of Product Innovation Management 25, 436 - 456. 
Veugelers, R. (1998), Collaboration in R\&D: An Assessment of Theoretical and Empirical Findings, De Economist 146(3), 419-443.

von Hippel, E. (1988), The Sources of Innovation. Oxford University Press, New York.

Von Stamm, B. (2004), Innovation - What's Design Got to Do with It, Design Management Review 15, 10 - 19.

Von Stamm, B. (2008), Managing Innovation, Design and Creativity, John Wiley and Sons, Chichester.

Walsh, V. (1996), Design, Innovation and the Boundaries of the Firm, Research Policy 25, $509-529$.

Yamamoto, M. and D. R. Lambert (1994), The Impact of Product Aesthetics on the Evaluation of Industrial Products, Journal of Product Innovation Management 11(4), 309-324. 


\section{Appendix A: Industry Classification}

Table 4: Sectoral classification for industry dummies

\begin{tabular}{c|llc}
\hline Number & Industry & $\begin{array}{l}\text { Industry definition according to NACE 2003 } \\
\text { sector classification }\end{array}$ & \# of obs. \\
\hline 1 & Textiles, Paper, Wood & $17,18,19,20,21,22$ & 144 \\
2 & Chemicals, Plastics & $23,24,25$ & 97 \\
3 & Metal & 27,28 & 139 \\
4 & Food and Beverages & 15,16 & 130 \\
5 & Machinery, Vehicles & $29,34,35$ & 150 \\
6 & Electronics & $30,31,32,33$ & 84 \\
7 & Other industries & $1,14,26,36,37,40,41,45$ & 130 \\
8 & Trade & $50,51,52$ & 203 \\
9 & Transport & $60,61,62,63,64$ & 180 \\
10 & Information Services & $72,73,74.2,74.3$ & 201 \\
11 & Other Services & $65,66,67,74$ (excl. 74.2, 74.3), 85, 90 & 37 \\
\hline
\end{tabular}

\section{Appendix B: Robustness Tests}

As the Tobit model is somewhat restrictive in its assumptions, we also employed other techniques. First, we performed OLS regressions. OLS has the advantage that it does not require the assumption of normality as the Tobit model, but it ignores the censoring of the dependent variable. The latter typically results in a downward bias of the estimated slope coefficients (see e.g. Greene, 2002). In our case, the OLS models, however, yield very similar results in terms of statistical significance and economic magnitude of the effects (see Tables 5 and 6). ${ }^{9}$

\footnotetext{
${ }^{9}$ Note that in contrast to the Tobit model, the estimated slope coefficients of the OLS regressions can directly be interpreted as marginal effects.
} 
Table 5: Results of OLS regressions on innovation performance (baseline specification)

\begin{tabular}{|c|c|c|c|}
\hline \multirow[b]{2}{*}{ Variable } & \multicolumn{3}{|c|}{ Dependent Variable (in logs) } \\
\hline & NEW_TO_MARKET & IMITATION & INNOVATION \\
\hline \multirow[t]{2}{*}{ DESIGN } & $1.097 * * *$ & $1.263^{* * *}$ & $1.490 * * *$ \\
\hline & $(0.253)$ & $(0.268)$ & $(0.249)$ \\
\hline \multirow[t]{2}{*}{$C O L L$} & $1.258 * * *$ & $1.220^{* * *}$ & $1.686 * * *$ \\
\hline & $(0.217)$ & $(0.220)$ & $(0.224)$ \\
\hline \multirow[t]{2}{*}{ MLAUNCH } & $2.661 * * *$ & $2.161 * * *$ & $3.108 * * *$ \\
\hline & $(0.263)$ & $(0.265)$ & $(0.262)$ \\
\hline \multirow[t]{2}{*}{ RDINT } & $0.045 * * *$ & 0.008 & $0.041 * * *$ \\
\hline & $(0.010)$ & $(0.009)$ & $(0.009)$ \\
\hline \multirow[t]{2}{*}{ RDINT2 } & $-0.000 * * *$ & -0.000 & $-0.000 * * *$ \\
\hline & $(0.000)$ & 0.000 & $(0.000)$ \\
\hline \multirow[t]{2}{*}{$\ln (E M P L)$} & $0.386 * * *$ & $0.507 * * *$ & $0.567 * * *$ \\
\hline & $(0.069)$ & $(0.077)$ & $(0.073)$ \\
\hline \multirow[t]{2}{*}{$\ln (A G E)$} & 0.001 & -0.137 & -0.080 \\
\hline & $(0.095)$ & $(0.098)$ & $(0 . .97)$ \\
\hline \multirow[t]{2}{*}{$G R O U P_{i}$} & -0.014 & 0.179 & 0.120 \\
\hline & $(0.137)$ & $(0.151)$ & $(0.154)$ \\
\hline Joint significance of industry. Dummies & $\mathrm{F}(9,1493)=2.24 * * *$ & $\mathrm{~F}(9,1493)=3.67 * * *$ & $\mathrm{~F}(9,1493)=3.93 * * *$ \\
\hline$R^{2}$ & 0.423 & 0.351 & 0.497 \\
\hline \# of obs & 1511 & 1511 & 1511 \\
\hline
\end{tabular}

Notes: All models include an intercept (not presented). Robust standard errors in parentheses.

$* * *(* *, *)$ indicate a $1 \%(5 \%, 10 \%)$ significance level. 
Table 6: Results of OLS regressions on innovation performance (modified specification)

\begin{tabular}{|c|c|c|c|}
\hline \multirow{3}{*}{ Variable } & \multicolumn{3}{|c|}{ Dependent Variable (in logs) } \\
\hline & NEW_TO_MARKET & IMMITATION & INNOVATION \\
\hline & $1.409 * * *$ & $1.397 * * *$ & $1.770^{* * *}$ \\
\hline & $(0.286)$ & $(0.301)$ & $(0.277)$ \\
\hline \multirow[t]{2}{*}{ EXT_DESIGN } & 0.219 & $0.886^{* *}$ & $0.789 * *$ \\
\hline & $(0.406)$ & $(0.452)$ & $(0.404)$ \\
\hline \multirow[t]{2}{*}{$A C O L L$} & 0.489 & $0.686^{*}$ & $0.766^{* *}$ \\
\hline & $(0.356)$ & $(0.381)$ & $(0.366)$ \\
\hline \multirow[t]{2}{*}{ BCOLL } & $0.675^{* *}$ & 0.176 & $0.754^{* *}$ \\
\hline & $(0.301)$ & $(0.299)$ & $(0.303)$ \\
\hline \multirow[t]{2}{*}{ CCOLL } & $1.017^{* * *}$ & $1.204^{* * *}$ & $1.206^{* * *}$ \\
\hline & $(0.348)$ & $(0.363)$ & $(0.355)$ \\
\hline \multirow[t]{2}{*}{ DCOLL } & -0.319 & 0.474 & $-0.633^{*}$ \\
\hline & $(0.381)$ & $(0.434)$ & $(0.367)$ \\
\hline \multirow{2}{*}{ ECOLL } & 0.162 & 0.566 & 0.176 \\
\hline & $(0.335)$ & $(0.356)$ & $(0.345)$ \\
\hline \multirow[t]{2}{*}{ FCOLL } & 0.081 & 0.407 & 0.023 \\
\hline & $(0.296)$ & $(0.331)$ & $(0.320)$ \\
\hline \multirow[t]{2}{*}{ MLAUNCH } & $2.193^{* * *}$ & $2.610^{* * *}$ & $3.153^{* * *}$ \\
\hline & $(0.263)$ & $(0.263)$ & 0.261 \\
\hline \multirow[t]{2}{*}{ RDINT } & $0.041 * * *$ & 0.006 & $0.037 * * *$ \\
\hline & $(0.010)$ & $(0.010)$ & $(0.010)$ \\
\hline \multirow{2}{*}{ RDINT2 } & $-0.000 * * *$ & -0.000 & $-0.000 * * *$ \\
\hline & $(0.000)$ & $(0.000)$ & $(0.000)$ \\
\hline \multirow[t]{2}{*}{$\ln (E M P L)$} & $0.351^{* * *}$ & $0.473^{* * *}$ & $0.528^{* * *}$ \\
\hline & $(0.069)$ & $(0.080)$ & $(0.075)$ \\
\hline \multirow[t]{2}{*}{$\ln (A G E)$} & 0.005 & -0.122 & -0.076 \\
\hline & (0.095) & $(0.097)$ & $(0.098)$ \\
\hline \multirow[t]{2}{*}{$G_{R O U P}$} & -0.131 & 0.050 & -0.034 \\
\hline & $\begin{array}{c}(0.139) \\
F(9.1493)=196 * *\end{array}$ & $\frac{(0.153)}{F(9.1493)=3.43 * * *}$ & $\frac{(0.158)}{F(9.1493)=364 * * *}$ \\
\hline \multicolumn{4}{|l|}{$\begin{array}{l}\text { Joint significance of industry dummies } \\
R^{2}\end{array}$} \\
\hline \# of obs & 1511 & 1511 & 1511 \\
\hline
\end{tabular}

Second, one might be concerned that design activities are to a certain extent endogenous to innovation performance, such that a firm that is highly innovative on all accounts may also be more likely to include design activities in its business strategy. Consequently, we tested for potential feedback effects from the dependent variables applying the Smith-Blundell (1986) test. The implementation is as follows:

(1) We run a regression of the design variable on all exogenous variables and one (or more) instrumental variable, and obtain the residuals from this regression. 
(2) We run the Tobit model as estimated above, but now also include the residuals obtained in step 1.

(3) The standard t-statistic of the coefficient of the included residuals is a valid test on endogeneity of the design variable. If the hypothesis that the coefficient of the residuals is not statistically significant is not rejected, we do not find endogeneity.

Performing the Smith-Blundell test requires an instrumental variable that is (a) exogenous meaning it is uncorrelated with any unobserved firm-specific factors affecting the firms' innovation performance; (b) relevant - meaning it has strong partial correlation with the design variable to avoid weak instrument bias. According to Staiger and Stock (1997) a partial F-value of the instrumental variable in the first stage regression should exceed ten.

As common in the literature, we use industry level averages of the possibly endogenous regressor as instrument. We calculated the fractions of firms employing design activities for 28 different industries, and use this detailed industry average as instrument for the design dummy. Such an industry average should be exogenous to unobserved firm-specific factors that may affect current innovation performance. When estimating the first stage of the SmithBlundell test, we find that our instrument is positively related to the design dummy, and highly significant. The partial F-statistic amounts to 10.10 (p-value: 0.0015 ) which rules out a weak instrument problem. Then we re-estimated all three Tobit models as presented in Table 2 but including the residuals from the first stage regression. It turned out that the hypothesis that the coefficient of these residuals is equal to zero was never rejected at any conventional level of significance. Therefore, we do not reject our assumption that the design dummy is an exogenous explanatory variable.

As a final robustness check, we performed an econometric matching. The descriptive statistics in Table 1 suggest that the firms employing design activities are quite different from the other companies, at least on average. Although we control for the different characteristics in our 
regressions, we had to assume some parametric functional form. In our final robustness test, we relax the functional form assumption using a fully non-parametric matching. For each firm in the design sample we search for the "nearest neighbour" in the control sample (the sample of firms not applying design activities) using a Mahalanobis distance matching (this has been applied frequently with CIS data in the context of policy evaluation. See e.g. Almus and Czarnitzki, 2003, Czarnitzki and Licht, 2006). For reasons of brevity, we refer the reader to surveys by Heckman et al. (1999) or Imbens and Wooldridge (2009) for the technical details. Table 7 shows how we implemented the matching for this study.

\section{Table 7: The matching protocol}

Step 1 Define $Z$ as matrix including the variables $\ln (E M P L)$, RDINT, MLAUNCH and COLL as matching arguments (those are the significant variables from the regressions discussed above).

Step 2 Choose one observation from the design subsample and delete it from that pool.

Step 3 Calculate the Mahalanobis distance between this firm and all non-design firms in order to find the most similar control observation.

$$
M D_{i j}=\left(Z_{j}-Z_{i}\right)^{\prime} \Omega^{-1}\left(Z_{j}-Z_{i}\right)
$$

$\Omega$ is the empirical covariance matrix of the matching arguments based on the sample of potential controls.

Step 4 Require that the nearest neighbor to be chosen is active in the same industry as the firm using design activities, i.e. drop all control observation from other industries.

Step 5 Select the observation with the minimum distance from the remaining sample. (Do not remove the selected controls from the pool of potential controls, so that it can be used again.)

Step 6 Repeat steps 2 to 5 for all observations in the design sample.

Step 7 Using the matched comparison group, the average effect of design can simply be calculated as the mean difference of the matched samples:

$\hat{\alpha}_{T T}=\frac{1}{n^{T}}\left(\sum_{i} Y_{i}^{T}-\sum_{i} \widehat{Y_{i}^{C}}\right)$

with $\widehat{Y_{i}^{C}}$ being the counterfactual for $i$ and $n^{T}$ is the sample size. Note that the same observation may appear more than once in the selected control group.

Step 8 As we perform sampling with replacement to estimate the counterfactual situation, an ordinary tstatistic on mean differences is biased, because it does not take the appearance of repeated observations into account. Therefore, we have to correct the standard errors in order to draw conclusions on statistical inference. We follow Lechner (2001) and calculate his estimator for an asymptotic approximation of the standard errors.

The results of the matching can be found in Table 8. As it can be seen, the previous heterogeneity in characteristics disappears as one balances the two groups of firms by nearest neighbor matching. For each of our 268 companies employing design activities we picked a 
nearest neighbor from the same industry. Now the two samples are comparable in terms of firm size, R\&D intensity, collaboration activity and the occurrence of market launch strategies. Yet, we still find differences in the innovation performance variables that may be assigned to the fact that some companies undertake efforts regarding the design of their innovative products. Similarly to the previous regression models, companies using design achieve $143 \%$ higher innovation sales than other companies of same size, with same R\&D intensity, and same occurrences of collaboration and market launch strategies. With regard to sales of market novelties, the difference amounts to $105 \%$. For imitation, it is $107 \%$. Note that the results also hold for the dependent variables in levels, except for the fact that the difference in imitation is not statistically significant. The latter, however, is largely due to the skewness of the distribution causing large standard errors in the t-test.

Table 8: Matching results ${ }^{\mathrm{a})}$

\begin{tabular}{lccccc}
\hline & \multicolumn{2}{c}{ firms with design activities } & \multicolumn{2}{c}{ Matched control group } & \multicolumn{2}{c}{$\begin{array}{c}\text { p-value of two- } \\
\text { sided t-test on mean } \\
\text { equality }\end{array}$} \\
& Mean & Std. Dev. & Mean & Std. Dev. & $\begin{array}{c}N_{0}=268 \\
\text { equal }^{\text {b }}\end{array}$ \\
\hline $\ln (E M P L)$ & 4.037 & 1.756 & 4.030 & 1.541 & 0.969 \\
RDINT & 12.541 & 2.174 & 10.267 & 32.188 & 0.781 \\
COLL & 0.590 & 0.493 & 0.597 & 0.491 & 0.883 \\
MLAUNCH & 0.649 & 0.478 & 0.634 & 0.483 & 0.764 \\
\hline $\ln (1+$ INNO) & 6.062 & 3.765 & 4.635 & 4.142 & 0.001 \\
$\ln (1+$ NEW_MARKET) & 4.695 & 3.844 & 3.668 & 0.234 & 0.010 \\
$\ln (1+$ IMITATION) & 4.383 & 4.010 & 3.318 & 3.953 & 0.010 \\
\hline
\end{tabular}

a) 10 industry dummies not reported. The treatment group and the control group are exactly matched on sectoral distribution.

b) t-statistics are based on Lechner's (2001) asymptotic approximation of the standard errors that accounts for sampling with replacement in the selected control group.

Given that the results of a fully non-parametric matching that does not rely on functional form assumptions or any distributional assumption are quite similar to the other regression results, our earlier results with the more restrictive models are reassuring, and do not reveal a serious misspecification. 